\title{
First record of herbivory of the invasive macrophyte Hedychium coronarium J. König (Zingiberaceae)
}

\author{
Wagner Antonio Chiba de Castro ${ }^{1,2,3}$, Marcel Loyo Moitas ${ }^{1,2}$, Gabriela Monteiro Lobato ${ }^{\text {, }}$ \\ Marcela Bianchessi da Cunha-Santino ${ }^{1,2}$ \& Dalva Maria da Silva Matos ${ }^{1,2}$ \\ ${ }^{1}$ Departament of Hydrobiology, Federal University of São Carlos - UFSCar, \\ CP 676, CEP 13565-905 São Carlos, SP, Brazil \\ ${ }^{2}$ Graduate Program in Ecology and Natural Resources, \\ Federal University of São Carlos - UFSCar, CP 676, 13565-905, São Carlos, SP, Brazil \\ ${ }^{3}$ Corresponding author: Wagner Antonio Chiba de Castro, e-mail: wagner.chiba@hotmail.com
}

CHIBA, W.A.C., MOITAS, M.L., LOBATO, G.M., CUNHA-SANTINO, M.B. \& SILVA-MATOS, D.M. First record of herbivory of the invasive macrophyte Hedychium coronarium J. König (Zingiberaceae). Biota Neotrop. 13(4): http://www.biotaneotropica.org.br/v13n4/en/abstract?short-communication+bn00913042013

Abstract: Invasive species can cause structural and functional changes in their non-native habitats, such as changes in the trophic chain. We describe ramet herbivory of butterfly ginger, an aggressive aquatic weed in Brazil, by capybaras in a floodplain area of a Cerrado reserve. This is the first record of herbivory of H. coronarium in invaded areas. Capybaras could be using the butterfly ginger as habitat and as a food resource, which could cause changes in apparent competition between these invasive and native macrophytes.

Keywords: butterfly ginger, aquatic weed, capybaras.

CHIBA, W.A.C., MOITAS, M.L., LOBATO, G.M., CUNHA-SANTINO, M.B. \& SILVA-MATOS, D.M. Primeiro registro de herbivora da macrófita invasora Hedychium coronarium J. König (Zingiberaceae). Biota Neotrop. 13(4): http://www.biotaneotropica.org.br/v13n4/pt/abstract?short-communication+bn00913042013

Resumo: Espécies invasoras podem causar alterações estruturais e funcionais nos ecossistemas invadidos, tais como alterações na cadeia trófica. Neste trabalho, descrevemos o primeiro registro de herbivoria de rametas de lírio-do-brejo, erva daninha aquática agressiva no Brasil, por capivaras em uma área de várzea de uma reserva de Cerrado. Este é o primeiro registro de herbivoria de rametas de $H$. coronarium em áreas invadidas. As capivaras desta região podem estar se utilizando dos bancos de lírio-do-brejo como habitat e como recurso alimentar, o que poderia ocasionar alterações na competição aparente entre esta invasora e as macrófitas nativas.

Palavras-chave: lírio-do-brejo, erva daninha aquática, capivaras. 
A species is considered invasive when it acquires a competitive advantage, in addition to the disappearance of natural obstacles to spread, allowing its rapid dispersal and dominance in a new habitat (Valery et al. 2008). This dominance causes structural and functional changes in these ecosystems (Mack \& D'Antonio 1998). Currently, biological invasion is considered the second biggest cause of global biodiversity loss (Wilcove et al. 1998, McGeoch et al. 2010). Changes in ecological processes, for example in food webs, are important impacts of invasive species (Vitousek 1990, Mack et al. 2000).

Aquatic macrophytes are among the most important global invasives, threatening biodiversity and ecosystem processes in aquatic environments (Pieterse \& Murphy 1990, Santamaria 2002). They spread rapidly, are able to grow and reproduce in sub-optimal conditions such as under intense competition (Spencer \& Bowes 1990) and exhibit rapid metabolism and large biomass in eutrophic ecosystems (Pieterse \& Murphy 1990). In Brazil, Hedychium coronarium J. König, Zingiberaceae, is an aggressive weed, invading floodplains, lake shores, streams and drainage channels, where it establishes dense populations (Couto \& Cordeiro 2005, Lorenzi 1991). It can reach up to $2.0 \mathrm{~m}$ tall, and is commonly named butterfly ginger (Macedo 1997, Santos et al. 2005, Instituto... 2012). It is native in tropical Asia and widely used for ornamental purposes (Kissmann \& Groth 1991). Due to its rapid growth and dispersal, it is considered an important weed that replaces the native vegetation (Santos et al. 2005). Our objective is to describe the first record of herbivory of these invasive macrophyte by capybara (Hydrochoerus hydrochaeris Linnaeus 1766)

From October 2011 to April 2013, we followed every two months a population of $H$. coronarium in 20 plots of $0.5 \mathrm{~m}^{2}$ located a floodplain area of ca. 0.8 ha, within the forest reserve of the Federal University of São Carlos (21 ${ }^{\circ} 58^{\prime} 15.00^{\prime}$ S and $47^{\circ} 53^{\prime} 16.45^{\prime}$ W). Each ramet of $H$. coronarium found was measured and marked with numbered tags to evaluate the population dynamics. From June to August 2012, we found in 7 plots grazed ramets associated with the disappearance or fragmentation of numbered plastic tags (Figure 1). Grazed ramets were all smaller than $25 \mathrm{~cm}$ height. No adult ramets were damaged or had tags missing or broken. In these plots, we found footprints and feces of $H$. hydrochaeris, a very common herbivore in this region. The fragments of the tags showed signs of $H$. hydrochaeris dental activity. H. hydrochaeris is a wild herbivore and the largest Brazilian rodent. Adults consume approximately $3 \mathrm{~kg}$ /day of fresh forage. Capybaras are selective grazers, and choose plants with high protein content (González-Jiménez 1978). According to Ferraz et al. (2007), capybaras are commonly found in large banks of $H$. coronarium, using them only as shelter from predators. Although rhizomes of these species have high quality nutritional content (Clippel et al. 2008), no signs of herbivory were observed, such as impressions of dental activity or revolving the sediments near the plants. The preference for $H$. coronarium ramets in early stages of development suggests that these plants have greater palatability and fewer secondary compounds than adult ramets (Bowers \& Stamp 1993).

The preferential herbivory of new ramets of $H$. coronarium could be attributed to a lower availability of other resources during the winter, when capybaras can present more opportunistic behavior than in periods of high resource abundance, as in spring (Borges \& Colares 2007). This is the first record of $H$. coronarium herbivory by capybaras and also the first record of herbivory of this macrophyte outside its native range. This record reinforces the need for further studies on the relationship between herbivory and invasive plants. Besides using the stands of $H$. coronarium as habitat (Ferraz et al.
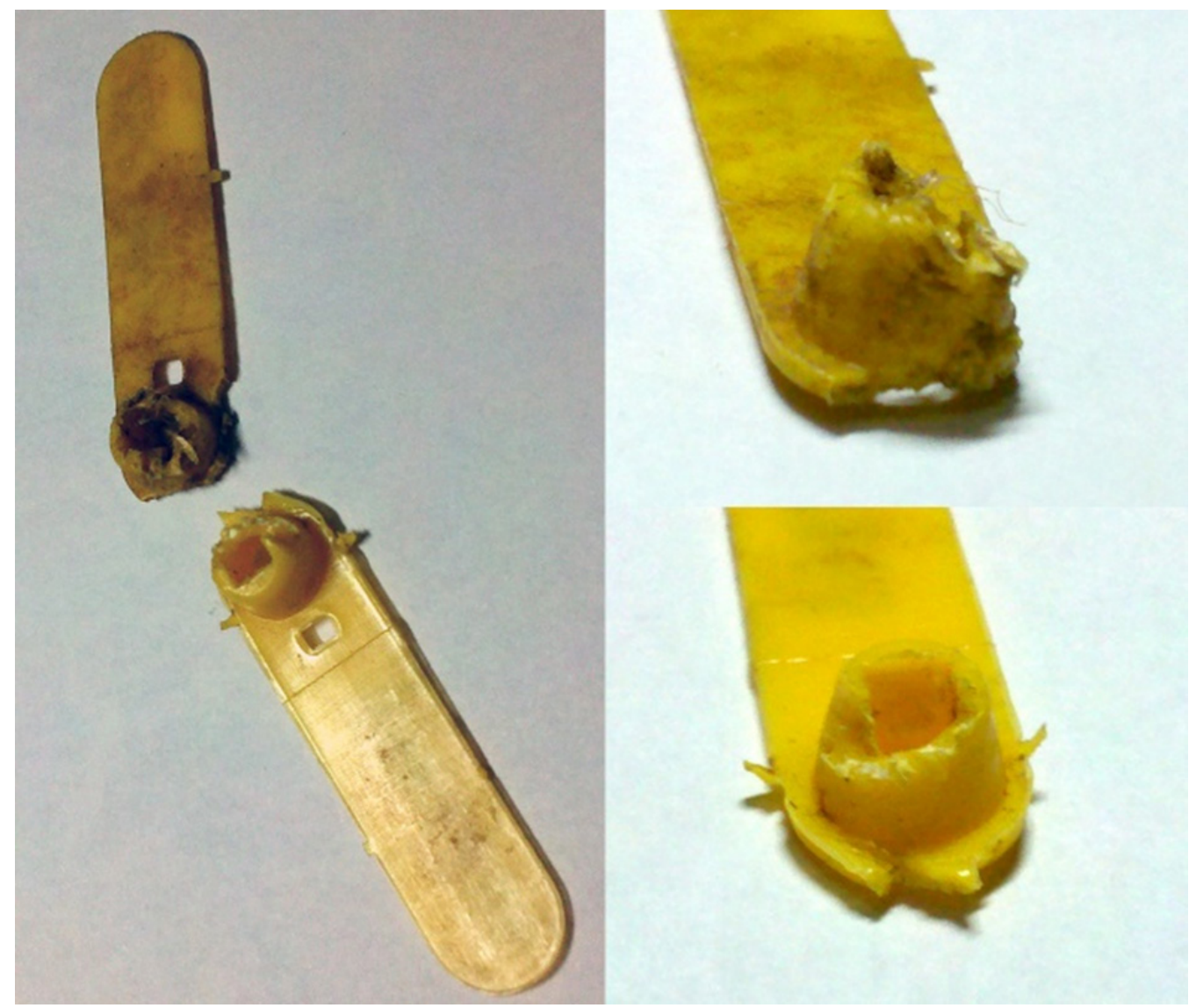

Figure 1. Numbered plastic tags bitten by capybara. 
2007) we observed that capybaras can also feed on them. This could affect the competitive capacity and also the apparent competition (Dangremond et al. 2010) between these invasive and native macrophytes. In this case, $H$. coronarium could benefit capybaras by offering favorable habitat protecting them from predators and adverse microclimatic situations besides serving as abundant food resource. These benefits would provide changes in the abundance and / or distribution of populations of capybara. As a result, these changes in capybara populations could change the rate of predation on, and also affect the population dynamics of, native species used primarily as its resource (Holt 1977, Holt \& Kotler 1987). Thus, these could ultimately allow the expansion of $H$. coronarium.

\section{Acknowledgements}

We thanks the National Council of Technological and Scientific Development (CNPq), and São Paulo Research Foundation (FAPESP) process number 2012/09485-4, at scientific support in the form of a scholarship to the first author. We thank prof. Dr. Michael Begon for suggestions that improved the quality of our work.

\section{References}

BORGES, L.V. \& COLARES, I.G. 2007. Feeding Habits of Capybaras (Hydrochoerus hydrochaeris, Linnaeus 1766), in the Ecological Reserve of Taim (ESEC -Taim) - South of Brazil. Braz. Arch. Biol. Technol. 50(3):409-416. http://dx.doi.org/10.1590/S1516-89132007000300007

BOWERS, M.D. \& STAMP, N.E. 1993. Effects of plant age, genotype, and herbivory on Plantago performance and chemistry. Ecology 74:17781791. http://dx.doi.org/10.2307/1939936

CLIPPEL, J.K., CARMO, H.N.C., NASCIMENTO, L.C.Z. \& CUZZUOL, G.R.F. 2008. Análise química em órgãos de reserva de algumas herbáceas e arbóreas ocorrentes na flora do Espírito Santo, Brasil. Acta Bot. Bras. 22(4):1057-1067. http://dx.doi.org/10.1590/S0102-33062008000400016

COUTO, O.S. \& CORDEIRO, R.M.S. 2005. Manual de reconhecimento de espécies vegetais da restinga do Estado de São Paulo. Centro de Editoração da Secretaria do Meio Ambiente, Departamento Estadual de Proteção de recursos Naturais, São Paulo.

DANGREMOND, E.M., PARDINI, E.A. \& KNIGHT, T.M. 2010. Apparent competition with an invasive plant hastens the extinction of an endangered lupine. Ecology 91:2261-2271. http://dx.doi.org/10.1890/09-0418.1

FERRAZ, K.M.P.M.B., FERRAZ, S.F.B., MOREIRA, J.R., COUTO, H.T.Z. \& VERDADE, L.M. 2007. Capybara (Hydrochoerus hydrochaeris) distribution in agroecosystems: a cross-scale habitat analysis. J. Biogeog. 34(2):223-230. http://dx.doi.org/10.1111/j.1365-2699.2006.01568.x

GONZÁLEZ-JIMÉNEZ, E. 1978. Digestive physiology and feeding of capybara (Hydrochaeris hydrochaeris). In Handbook series in nutrition and food (M. Recheigl, ed.). CRC Press. Cleveland. Sept. 9(1):163-177.

INSTITUTO HÓRUS DE DESENVOLVIMENTO E CONSERVAÇÃO AMBIENTAL. Espécies Exóticas Invasoras: Fichas técnicas. http:// www.institutohorus.org.br/index.php?modulo=inf_ficha_hedychium coronarium (último acesso em 01/09/2012).

HOLT, R.D. 1977. Consumption, apparent competition, and the structure of prey communities. Theor. Popul. Biol. 12:197-229. http://dx.doi. org/10.1016/0040-5809(77)90042-9

HOLT, R.D. \& KOTLER, B.P. 1987. Short-term apparent competition. Am. Nat. 130:412-430. http://dx.doi.org/10.1086/284718

KISSMANN, K.G. \& GROTH, D. 1991. Plantas infestantes e nocivas. Basf Brasileira, São Paulo, p.590-593.

LORENZI, H. 1991. Plantas daninhas do Brasil: terrestres, aquáticas, parasitas, tóxicas e medicinais. 2. ed. Instituto Plantarum, Nova Odessa.

MACEDO, J.F. 1997. O gênero Hedychium Koening (Zingiberaceae) no Estado de Minas Gerais. Daphne 7(2):27-31.

MACK, R.N., SIMBERLOFF, D., LONSDALE, W.M., EVANS, H., CLOUT, M. \& BAZZAZ, F. 2000. Biotic invasions: causes, epidemiology, global consequences and control. Ecol. Appl. 10:689-710.

MACK, M.C. \& D’ANTONIO, C.M. 1998. Impacts of biological invasions on disturbance regimes. Trends Ecol. Evol. 13(5):195-198. http://dx.doi. org/10.1016/S0169-5347(97)01286-X

McGEOCH, M.A., BUTCHART, S.H.M., SPEAR, D., MARAIS, E., KLEYNHANS, E.J., SYMES, A., CHANSON, J. \& HOFFMANN, M. 2010. Global indicators of biological invasion: species numbers, biodiversity impact and policy responses. Divers. Distrib. 16(1):95-108. http://dx.doi.org/10.1111/j.1472-4642.2009.00633.x

SANTOS, S.B., PEDRALLI, G. \& MEYER, S.T. 2005. Aspectos da fenologia e ecologia de Hedychium coronarium (Zingiberaceae) na estação ecológica do Tripuí, Ouro Preto-MG. Planta Daninha 23(2):175-80. http:// dx.doi.org/10.1590/S0100-83582005000200002

PIETERSE, A.H. \& MURPHY, K.J. 1990. Aquatic Weeds. The Ecology and management of Nuisance Aquatic Vegetation. Oxford Science Publications, Oxford.

SANTAMARIA, L. 2002. Why are most aquatic plants widely distrited? Dispersal, clonal growth and small-scale heterogeneity in a stressful environment. Acta Oecol. 23:137-154. http://dx.doi.org/10.1016/S1146609X(02)01146-3

SPENCER, W. \& BOWES, G. 1990. Ecophysiology of the world's most troublesome aquatic weeds. In Aquatic weeds. The ecology and management of nuisance aquatic vegetation (A.H.Pieterse \& K.J. Murphy, ed.). Oxford Science Publications, New York, p.40-51.

VALERY, L., FRITZ, H., LEFEUVRE, J.C. \& SIMBERLOFF, D. 2008. In search of a real definition of the biological invasion phenomenon itself. Biol. Invas. 10:1345-1351. http://dx.doi.org/10.1007/s10530-007-9209-7

VITOUSEK, P.M. 1990. Biological invasions and ecosystem processes: towards an integration of population biology and ecosystem studies. Oikos 57(1):7-13. http://dx.doi.org/10.2307/3565731

WILCOVE, D.S., ROTHSTEIN, D., DUBROW, J., PHILLIPS, A. \& LOSOS, E. 1998. Quantifying threats to imperiled species in the United States. BioScience 48:607-615. http://dx.doi.org/10.2307/1313420 